\title{
Punishment Analysis at School Based on Article 54 of the Child Protection Act in Law Number 35 of 2014
}

\author{
Hotma Siregar ${ }^{1}$, Atika Rahmi ${ }^{2}$ \\ ${ }^{1,2}$ FKIP Universitas Muhammadiyah Sumatera Utara, Indonesia \\ hotmasiregar@umsu.ac.id
}

\begin{abstract}
The purpose of this study, to adjust the form of regulations made by schools with the provisions of Law Number 35 of 2014 concerning Child Protection. Research conducted is qualitative research by conducting documentation and observation studies to obtain more accurate data. Documentation study is conducted to study and analyze the contents of the regulations that were applied in SMP 2 Helvetia. Observations are made to the school to see firsthand whether sanctions against violations of the rules given to students are in accordance with the Article 54 of the Child Protection Act. The results of this study, designed a form of regulation that will be applied in schools, where the punishment given in the event of a violation by students must be humane and still protect the rights of the child. If viewed from the provisions of Article 54 of Law Number 35 of 2014 concerning Child Protection, then the execution of the Punishment in SMP PAB 2 Helvetia does not violate the provisions of Article 54 of Law Number 35 of 2014, where the child is in an educational unit (school) has been protected from acts of physical and psychological violence, this is evidenced by the absence of physical punishment in the school environment and the enactment of a point system which means that teachers and other education personnel have sought ways to punish students who violate the rules clearly and to avoid physical punishment.
\end{abstract}

Keyword : punishment; child protection laws

\section{Introduction}

School is a formal educational institution that is obliged to prepare the next generation of the Indonesian nation to become citizens who love the country. The function of the school is realized in the form of continuing the noble values of Pancasila and the formation of the Indonesian personality, attitude, morals and mentality. To achieve this goal, each school is expected to improve its quality and quality. One way to improve the quality of education is by creating or compiling school rules or rules along with sanctions / penalties for students who violate these rules. The rules or rules of the student then become a guideline or reference for students in thinking, behaving, behaving and acting. But in reality on the ground, the teacher still often gives punishments that harm the physical and psychological aspects of his students.

Everyone certainly does not want the occurrence of violence, especially in educational institutions which should resolve the problem peacefully and educatively. But in reality there are still many, even almost all schools / madrassas have not been able to provide children's rights, even commit violence against children. Without realizing it, it is a violation of the Law of the Republic of Indonesia Number 35 of 2014 concerning Amendment to Law Number 23 of 2002 concerning Child Protection (henceforth read: Child Protection Act) and International Convention on the rights of children.

Education in Indonesia basically must be in accordance with the laws in Indonesia. But in reality there are still many teachers who do not understand and understand how the pattern of education and the process of providing good punishment for children in accordance with the Child Protection Law, and in the end many of the media both print and electronic media reported news about teachers imprisoned for taking action inappropriate for their students. 
On the other hand, there were also teachers who heeded the presence of the Child Protection Act, but in their duties the teacher also seemed to be looking safe namely continuing to carry out education but the implementation was not maximal so sentences were rarely given or even never given, changes in the teacher's education pattern due to various something of which is due to fear of being reported to the police for punishment, even though educative punishment is also a coaching that must be given by the teacher to form a good and moral character of course.

The Child Protection Act is a regulation that discusses the rights and obligations of children and the rights, obligations and authority of parents to children and all kinds of things relating to it which hope to protect children's rights so that children can grow and develop and participate optimally accordingly with the dignity and dignity of humanity, and get protection from violence and discrimination, for the realization of quality Indonesian children, noble and prosperous (Article 3 of the Law on Child Protection). However, there is a possibility that there are still child rights violated in the world of education, for example in the provision of physical punishment.

Article 16 paragraph (1) of the Child Protection Act states that: "every child has the right to receive protection from inhumane torture, torture, or imposition of punishment." In the above article in the last section it is written that inhumane law is taken, this means there is human punishment.

In the world of pedagogical, giving punishment is a natural thing, if the suffering caused by the punishment contributes to the moral development of students. Children also have the obligations stated in Article 19 of the Child Protection Act, namely that each child is obliged to: a). Respect for parents, guardians, and teachers; b). Loving family, community and loving friends; c). Love the homeland, nation and state; d). Perform worship according to his religion, and e). Carry out ethics and noble character.

In fact, there are still many children who until now have not realized that they have an obligation to respect parents and teachers and carry out other obligations as stated in Article 19 of the Child Protection Act. Therefore teachers are required to be more diligent in educating students. Giving punishment must be carried out appropriately. To prevent these things, the teacher must be able to understand the Child Protection Act.

Article 54 of the Child Protection Act explains that: "Children in the school environment must be protected from acts of violence committed by teachers, school administrators, or friends in the relevant school or other educational institutions". By understanding Article 54 of the Child Protection Act, it is hoped that the implementation of education can run well and does not harm both parties both students and teachers.

Child protection is an embodiment of the existence of justice in a society so that the protection of children is cultivated in various fields of life and state of society. Child Protection According to Arief Gosita in Anggia Maulana Sari (2008: 28) "Child protection is a joint activity aimed at securing the procurement and fulfillment of children's spiritual and physical welfare in accordance with their interests and human rights".

Whereas according to Maidin Gultom (2010: 33) "child protection is all efforts made to create conditions so that every child can exercise his rights and obligations for the development and growth of children in a reasonable manner both physically, mentally, and socially".

Based on the opinion above, it can be concluded that child protection is an action carried out consciously by someone who has grown up to protect children from all possibilities that are able to threaten growth and development to achieve prosperity. 
Article 1 point (1) of the Child Protection Act explains in more detail that: child protection is all activities to guarantee and protect children and their rights so that they can live, grow, develop and participate, optimally in accordance with human dignity and protection, and get protection from violence and discrimination.

Children are the mandate and grace of the One and Only God who inherits the dignity and dignity as a whole person. Every child has dignity that deserves to be upheld and every child who is born must get his rights without the child having to ask.

In conducting efforts to protect children, they should not be carried out excessively, meaning that the business must also pay attention to the impact on the environment and the child's own development. Thus protection of children must be carried out in a rational, responsible and beneficial manner that reflects an effective and efficient business. Child protection must also not lead to the death of initiative, creativity, and other things that can cause dependence on others and behave uncontrollably, so that children do not have the ability and willingness to use their rights and carry out their obligations (Maidin Gultom, 2010: 33).

Article 54 of the Child Protection Act states explicitly that children in the school environment must get protection from all forms of violence, both physical and psychological violence, educators and education personnel who are in school must provide protection for children as students. This also confirms that in giving punishments to school students and educators must heed the presence of Law No. 35 of 2014 concerning the protection of children.

The birth of the Child Protection Act in Indonesia aims to provide protection for children and guarantee the fulfillment of children's rights so that they can grow, develop and participate optimally in accordance with human dignity and receive protection from violence and discrimination for the realization of quality, moral Indonesian children. noble and prosperous.

Based on the background above, the researcher formulated an emerging problem, namely: about the punishment given to students who violated school regulations made by SMP PAB 2 Helvetia in accordance with the provisions of the sound Article 54 of Law Number 35 of 2014 concerning Child Protection.

This study aims to analyze whether the sanctions given by SMP PAB 2 Helvetia against violations of regulations carried out by students are contrary to the sound of Article 54 of Law Number 35 of 2014 concerning Child Protection. Article 54 reads "Children in and within the education unit must obtain protection from acts of physical, psychological, sexual crimes and other crimes committed by educators, education personnel, fellow students and / or other parties". Protection as mentioned above is carried out by educators, education staff, government officials or the public to fulfill children's rights in obtaining protection from various acts of violence.

The benefits of the results of this research are:

1. For the community,

The results of this study will provide benefits to the community in general, especially parents to find out more that there are child rights that must be protected when the child is in the school environment. Thus, parents can report to the authorities if there is a violation of the rights of their children in the school environment, whether done by educators, education staff, peers and other parties. According to the Explanation of Law No. 35 of 2014 what other parties mean is school guards, school gardeners, ...

2. For Schools,

Through the results of this study, the school is more concerned about making regulations that are educational in nature. Educators must better understand that giving punishment for their students' mistakes must be punished that does not conflict with the law. Every educator 
must respect all of his students, without exception. Educators must not give penalties or sanctions to students in the form of physical or psychological violence. Educators cannot just hit, kick, tweak or even insult or issue words that are degrading to students. If this is still done by educators, parents / guardians can report the educator to the police.

\section{Research Methods}

This research is qualitative descriptive, which is one type of research that is included in the type of qualitative research. The object of this research is the regulation made at SMP PAB 2 Helvetia Medan, located on Jl Veteran Pasar IV Medan Helvetia which is included in the Deli Serdang Regency area. In accordance with the type of research, then the contents of the regulations made at the school will be analyzed based on Article 54 of the Child Protection Act No. 35 of 2014.

Before the analysis is carried out, the researcher first conducts observations to obtain data on school conditions and what sanctions are given to students who violate school regulations. The researcher also collected various literature related to the research title as reference material to be able to carry out the analysis. The literature is needed among others: the Child Protection Act, the Human Rights Law, the Education System Law and includes books that are in accordance with the research title.

\section{Result and Discussion}

Analysis of the content of SMP PAB 2 regulations is carried out based on the sound of Article 54 of the Child Protection Act Number 35 of 2014 producing:

\subsection{Regulation Form of SMP PAB 2 Helvetia Medan}

SMP PAB 2 Helvetia is a Junior High School located on Jl Veteran Pasar IV Medan Helvetia which is included in the Deli Serdang Regency area. This school is located right on the edge of the Medan-Belawan highway. Good road access and the many choices of city transportation also make it easier for students to get to school

In order to realize conducive and better learning, each school must have a strategy applied in handling and minimizing the occurrence of violations of discipline. For this reason, SMP PAB 2 Helvetia makes and implements school regulations that must be adhered to by all students in SMP PAB 2 Helvetia to improve student discipline. School regulations also sometimes have to include punishment as an educational tool. Penalties are given to every student who commits a violation.

To reduce the number of violations, the school takes a policy by implementing a "point system" in school rules. The point system policy is a policy whereby every student who violates the school order will be given a score with certain points depending on the type of violation committed and the points will be accumulated whenever the student commits a violation. This technique of score points is used to be able to find out how many violations are committed by students. This is given so that students can be more orderly towards themselves and behave in school in accordance with school discipline. The following is a credit data table for students who commit violations as follows:

Table 1. Credit Points Data for Student Violations of Discipline

\begin{tabular}{|c|c|c|}
\hline No & Types of Violations & Score Points \\
\hline
\end{tabular}




\begin{tabular}{|c|c|c|}
\hline 1. & Come to school late & 5 \\
\hline 2. & Not coming to school without notice & $5-10$ \\
\hline 3. & Leave class when during the lesson & 10 \\
\hline 4. & Go / buy food in the canteen during the lesson & 5 \\
\hline 5. & Not doing homework, assignments and teacher training & 5 \\
\hline 6. & Littering, eating gum and not sweep the class & 5 \\
\hline 7. & Not carrying personal book and juz amma & 5 \\
\hline 8. & Use excessive accessories & 5 \\
\hline 9. & Make a noise in class and school environment & 10 \\
\hline 10. & Do not want to do prayers & 10 \\
\hline 11. & $\begin{array}{l}\text { Lying / saying dirty / insulting / mocking / threatening / disturbing } \\
\text { others }\end{array}$ & 10 \\
\hline 12. & Clothing is not in accordance with applicable regulations & 10 \\
\hline 13. & Activate the cellphone in class during the lesson & 10 \\
\hline 14. & Long hair / haircut not according to school rules & $5-10$ \\
\hline 15. & Damaging school facilities and infrastructure & $10-25$ \\
\hline 16. & Make group & 20 \\
\hline 17. & $\begin{array}{l}\text { Do not submit a parent summons, falsify the signature of the parent } \\
\text { / guardian }\end{array}$ & 20 \\
\hline 18. & Not paying SPP for 3 months & 25 \\
\hline 19. & Smoking, gambling, stealing and carrying sharp objects & 50 \\
\hline 20. & Fighting teachers, staff and school employees & 50 \\
\hline 21. & Fighting & 50 \\
\hline 22. & $\begin{array}{l}\text { Bring, see and trade books, magazines, VCDs and pornographic } \\
\text { images }\end{array}$ & 50 \\
\hline 23. & Immoral acts with all causes & 100 \\
\hline 24. & Tattooing, piercing, drugs, drinking liquor & 100 \\
\hline 25. & Get merried & 100 \\
\hline
\end{tabular}

Violation score will be accumulated per semester with the following conditions:

1. Scores $<25$ coaching by Homeroom Teacher

2. Scores $>25$ SPO 1 and coaching by BK

3. Scores $>50$ SPO 2 and guidance by BK and PKS 3

4. Scores $>75$ SPO 3 Coaching by BK, PKS 3 and Principal

5. Scores $>100$ is returned to parents

From the table above, it is known that students who violate school rules will be given points according to the violations they committed, then the points obtained by students for the violations they do will be accumulated within 1 semester and if they have reached a certain point then the student will given coaching action by the Mayor, Counseling Guidance Teacher, Deputy Principal for Student Affairs and Principal.

With the point system, it is expected that violations of school regulations will decrease and there will be an increase in student discipline to comply with existing regulations in schools, besides SMP SMP PAB 2 Helvetia also uses personal books as report books for violations committed by students. Personal books are useful for knowing the types and number of disciplinary violations that are directly recorded and given scores / points, because in this personal book also included points for each violation. 
With the existence of personal books, teachers can easily find out what violations are committed by students and what penalties should be given according to their violations. This personal book also functions as one of the preventive actions taken by the teacher. With the record of violations made, the students will be afraid to commit violations because this private book will be taken home by students so that the parents know their child's attitude while in the school environment. In implementing the code of conduct, the school really needs cooperation with parents so that parents know the rules that are in school so parents know what their children do not adhere to in the school environment. This is evidenced by the existence of a private book in which contains a report about the behavior of students in school to be given to parents of students. Thus the communication made by the school to the parents of students has been well implemented.

\subsection{Analysis of Sanctions for Regulation Violations of SMP PAB 2 Helvetia Medan on Article 54 of Law No. 35 of 2014}

The Child Protection Act is a law that shows that the Indonesian people are a nation that upholds human rights, including the rights of children. Countries, governments, communities, schools and parents are obliged to provide protection and guarantee the fulfillment of children's human rights because children are an integral part of human survival and the survival of a nation and country. Every child needs to get the widest opportunity to grow and develop optimally both physically, mentally and socially. without discriminatory treatment.

Fulfillment of children's rights, not only when children are at home, but including when children are in the school environment. This is explicitly regulated in Article 54 of the Protection Act which reads "Children in and within the education unit must receive protection from acts of physical, psychological, sexual crimes and other crimes committed by educators, education personnel, fellow students and / or parties other". Protection as mentioned above is carried out by educators, education staff, government officials or the public to fulfill children's rights in obtaining protection from various acts of violence.

The acts of violence referred to in Article 54 of Law Number 35 of 2014 are classified into 2 forms, namely physical and psychological forms. Physical violence can be identified in the form of beatings (using hands and tools), sightings and kicks. Whereas, psychic violence includes acts of mocking or insulting, intimidating and showing an attitude or expression of displeasure, and actions or sayings that hurt other people's feelings.

Students who violate the provisions stated in the school order at SMP PAB 2 Helvetia will be subject to the following sanctions:

1) Reprimand

2) Assignment

3) Confiscating items that are not allowed to be taken to school

4) Summoning parents

5) Suspension

6) Expelled from school

Reprimand is a type of sanction given by a teacher to a student if the student is found to have a minor offense, such as a violation of clothing and does not use school attributes completely, late, and disturbs friends during the lesson. If analyzed based on Article 54 of the Law on Child Protection, then sanctions in the form of reprimand are not contradictory.

Giving assignments is also a type of sanction given by picket teachers for students who are late and do not carry the assignments given by the teacher. For students who are late, the assignment given is in the form of memorizing short Qur'anic suras. Students who are late must 
deposit the surah memorization given to him as the entrance ticket to attend the lesson. The task given to students who do not do the task is to do assignments that were not done before by the student and in addition summarize the material that has been studied before.

Punishment by way of assignment is one of the educational penalties without the slightest use of violence, this sentence aims to provide a deterrent effect on violations committed by students.

Suspension is a type of punishment given by the teacher to students who commit serious violations such as fighting and carrying prohibited items. Sanctions in the form of scores also involve the role of parents in providing supervision and guidance to their children during the score period. Students who are suspended are students who have had more than 75 points of violation points. Giving the point system is also intended to eliminate the occurrence of physical punishment at school.

If there are students who commit violations such as fighting and carrying drugs, it will be processed by involving parents, homeroom and vice principal of the student field. In this case the school considers the need for cooperation of parents, with the teacher to improve student learning order. Cooperation between teachers and parents must be fostered intensively, and proactively when students commit violations at school. This is by inviting parents of students to attend meetings at school in solving problems related to personal learners. Summoning parents of students who commit violations with a certain score score shows that the school establishes very good communication with parents of students.

Removing students from school is the final step taken by the school if reprimand and other punishments and coaching processes do not succeed in changing the behavior of students who continue to violate, but this is very rarely given because usually after being given guidance, students will change their behavior.

The acts of violence referred to in Article 54 of Law Number 35 of 2014 are classified into 2 forms, namely physical and psychological forms. Physical violence can be identified in the form of beatings (using hands and tools), sightings and kicks. Whereas, psychic violence includes acts of mocking or insulting, intimidating and showing an attitude or expression of displeasure, and actions or sayings that hurt other people's feelings. If we associate the violence referred to in Article 54 with the imposition of sanctions in SMP PAB 2 Helvetia, there is no conflict found.

This can be clarified again by looking at the forms of sanctions given to students who violate the rules that are not contradictory, both physically and psychologically. In fact, the punishment given to students who violate school rules in SMP PAB 2 Helvetia in the form of reprimand and rote memorization assignments in short suras, or summarizing the subject matter will actually improve students' competence personally. Whereas sanctions in the form of suspension are the final steps taken by the school if the reprimand and other penalties and the coaching process are not successful in changing student behavior and still continue to commit violations. But this is very rarely given because usually after being given guidance, students will change their behavior

If viewed from the provisions of Article 54 of Law Number 35 of 2014 concerning Child Protection, the implementation of the award of Punishment in SMP PAB 2 Helvetia does not violate the provisions of Article 54 of Law Number 35 of 2014 where children in an education unit (school) have protected from acts of physical and psychological violence, this is evidenced by the non-enforcement of physical punishment in the school environment and the enactment of a point system which means that teachers and other education personnel have sought ways to punish students who violate these regulations clearly and to avoid punishment physical. 


\section{Conclusion}

Based on the results of the study, it can be concluded that: if viewed from the provisions of Article 54 of Law Number 35 of 2014 concerning Child Protection, the implementation of the sentence in SMP PAB 2 Helvetia does not violate the provisions of Article 54 of Law Number 35 of 2014, where the child in an education unit (school) has been protected from acts of violence both physically and psychologically, this is evidenced by the non-enforcement of physical punishment in the school environment and the enactment of a point system which means that teachers and other education personnel have sought ways to punish students who violate these rules are clear and to avoid physical punishment.

Thank-you notes

This research could not have been carried out without the help of many parties. For this reason, researchers need to thank:

1. Mr. Rahman Hadi, S.P, as the Headmaster of SMP PAB 2 Helvetia Medan who gave permission to researchers to conduct research at the school.

2. Mr. Indrawan Sitorus as the Vice principal of the Curriculum Field who has provided information on the regulations applied at SMP PAB 2 Helvetia Medan.

3. UMSU Faculty of Teacher Training and Education Dean who has assisted researchers in providing needed information.

4. Chairperson of the Research and Community Service Institute of university of Muhammadiyah Sumatera Utara, which has provided opportunities for researchers to follow UMSU's internal research.

\section{References}

Ahmadi, Abu. 2003. Ilmu pendidikan. Jakarta: PT Rineka Cipta

Article 54 of Law Number 35 of 2014

Gultom, Maidin. 2012. Perlindungan Hukum Terhadap Anak dan Perempuan, Bandung: PT Refika Aditama

Gultom, Maidin. 2014. Perlindungan Hukum Terhadap Anak dalam Sitem Peradilan Pidana Anak di Indonesia, Bandung: PT Refika Aditama

Hasbullah. 2009. Dasar-dasar Ilmu Pendidikan. Jakarta:Rajawali pers.

Saraswati, Rika. 2015. Hukum Perlindungan Anak di Indonesia, Bandung : PT Citra Aditya Bakti

Sugiono, 2012. Metode Penelitian Pendidikan. Bandung: Alfabeta

Tirtahardja, Umar. 2008. Pengantar Pendidikan. Jakarta: PT Rineka Cipta 